\title{
Science education in Indonesia: past, present, and future
}

\author{
Faisal $^{1,2}$ and Sonya N. Martin $3^{3^{*}}$
}

\author{
* Correspondence: \\ sonya.n.martin@gmail.com \\ ${ }^{3}$ Earth Science Education \\ Department, Seoul National \\ University, Seoul, Republic of Korea \\ Full list of author information is \\ available at the end of the article
}

\begin{abstract}
The purpose of this paper is to describe pre- and in-service science teacher education and science education research in Indonesia in an effort to better inform the international science education community about historical developments and present challenges. We begin by providing an historical overview of the general education system to provide readers with context needed to understand current reform initiatives. Next we describe the current-day process for preparing and certifying science teachers and we describe some of the challenges facing teachers, students, and researchers in Indonesia's science education context today. We follow this discussion with an introduction to some existing professional organizations for teachers and researchers in Indonesia that are working to develop important channels for disseminating current research on teacher practice, curriculum innovation, and student learning that have the potential to positively influence on teaching and learning in the future. We conclude by highlighting some areas that would benefit from additional research and by inviting more international collaborative research initiatives with colleagues in the Asia-Pacific region and beyond.
\end{abstract}

Keywords: Science education, Indonesia, History, Science teacher education

\section{Ringkasan}

Tujuan dari penulisan artikel ini adalah untuk mendeskripsikan program pendidikan calon guru dan guru sains, serta penelitian pendidikan sains di Indonesia sebagai upaya untuk menginformasikan kepada komunitas pendidikan sains internasional mengenai sistem pendidikan yang dijalankan oleh pemerintah dan tantangan yang dihadapi. Kami mengawali dengan menguraikan sejarah perkembangan sistem pendidikan di Indonesia sebagai konteks bagi pembaca untuk memahami beberapa inisiatif yang telah dilakukan oleh pemerintah. Pada bagian berikutnya, kami menguraikan proses pendidikan dan sertifikasi guru dan beberapa tantangan yang dihadapi oleh guru, siswa, maupun peneliti, khususnya pada konteks pendidikan sains sekarang ini. Kami juga mendeskripsikan peran penting organisasi profesi guru dan Lembaga Pendidikan Tenaga Kependidikan (LPTK) dalam mendukung perkembangan dan penyebarluasan penelitian-penelitian kependidikan, baik yang terkait dengan peningkatan kompetensi guru, inovasi kurikulum, maupun aktivitas belajar siswa, yang seluruhnya berpotensi meningkatkan kualitas praktik-praktik pembelajaran dimasa depan. Pada bagian akhir, kami menyimpulkan dengan menyoroti beberapa aspek yang akan mendapat manfaat dari hasil-hasil penelitian dan dengan mengajak lebih banyak inisiatif terhadap penelitian kolaboratif internasional bagi peneliti-peneliti pendidikan sains di kawasan Asia-Pasifik maupun pada lingkup internasional yang lebih luas. 


\section{Introducing the Indonesian education system}

In this section, we describe some significant developments in the education system and we highlight the ways in which educational policy has been used to try to provide an education for a very diverse group of learners. Understanding how and why the education system has developed and changed over time will enable readers to appreciate the present-day challenges faced by science teacher educators, researchers, teachers, and students in Indonesia and offers some context for considering what issues are significant to address in the future. The Indonesian education system has undergone a great deal of transformation starting from the pre-colonial and colonial era through the early years of independence until today. We highlight significant transformations and events impacting on policy and practice related to student enrollment and access to school, teacher preparation and certification processes, and national science curriculum and resource development. A cursory search of research published in international science education journals reveals very few studies describing science education in Indonesia. This paper seeks to fill this gap by contributing to readers' improved understanding about Indonesia's science education research context.

\section{Historical developments}

Indonesia is positioned along the equatorial line separating the Indian and Pacific oceans and consists of an estimated 17,500 islands covering nearly 1,913,000 km² (BPS, 2016). ${ }^{1}$ As such, it is the largest archipelagic country in the world. Indonesia's geographic location and plentiful natural resources has historically made the islands a critical part of international trade and has had lasting consequences for Indonesia's economy and society. During the 1500-1600s, Indonesia became a hub for trading among merchants from countries in the Middle East, Europe, and India. In the late sixteenth century the Dutch East India Company forcibly colonized Indonesia and took control of its land and resources. The trading company came to be administered by the Dutch government in 1800 .

By 1819, the territory became an official colony of the Netherlands called the Dutch East Indies. During the colonial era, the Dutch introduced limited public and private schooling reserved solely for the Dutch and other Europeans. In 1870, some schools

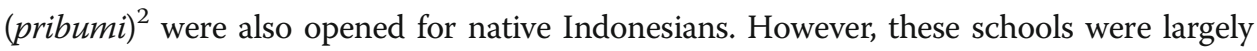
underfunded, provided only 2 or 3 years of training in basic literacy and math, and were mainly located in urban areas. Before colonialism, there was no systemic national education program; however, Hindu, Buddhist, and Islamic schools provided religious education for their followers. During colonial rule, education in rural areas continued to be left to religious organizations, including Christian missionaries and Muslim religious schools.

By the 1920s, it is estimated that less than $7 \%$ of the native population was literate, with the literate population being located only in the urban centers and on large islands (Munandar, 1990). In the 1920s and 1940s, the Dutch established some medical schools, trade schools, arts and agriculture schools. Several of these schools evolved into present day universities, including Indonesia University (Universitas Indonesia [UI]), Bandung Institute Technology (Institut Teknologi Bandung [ITB]), and Bogor Agriculture Institute (Institut Pertanian Bogor [IPB]). Today these universities are ranked among the best in the country (Azra, 2008; Hill \& Thee, 2012). Lack of access to educational opportunities for native populations contributed to growing anti-colonial sentiment among middle- and 
upper-class Indonesians. However, the Dutch continued to occupy the lands, control the natural resources, and rule over the people of Indonesia until the 1940s when the Netherlands was occupied by Germany during World War II. This time period was very volatile as there was a growing movement among Indonesian nationalists to proclaim their independence from the Dutch. In 1942, with the Dutch unable to defend the colony, the Japanese invaded and occupied Indonesia. Initially, some Indonesians who had sought to escape Dutch colonial rule welcomed the Japanese invasion. During their occupation of Indonesia, the Japanese introduced the first system of mass education, which opened schools for all students and supported the use of local languages for instruction (Bangay, 2005). However, similar to the Dutch colonial schools, education in these schools were designed to support the needs of Japan as an occupying power rather than promote the educational development of native Indonesians. The Japanese remained present until the end of the war in 1945.

\section{Post-colonial developments}

Sukarno, leader of the Indonesian nationalist movement, declared independence from both the Dutch and Japanese on August 17, 1945. Sukarno served as Indonesia's first post-colonial era president from 1945 to 1967. During the post-colonial period, Sukarno and his government worked to establish and develop an education system that could unify a large and diverse population of people. Following the end of the second world war, few teachers or principals were left to manage the school system as the vast majority of educators had been members of the colonial powers and were no longer in power. Sukarno successfully led Indonesia to resist Dutch efforts to recolonize the country until 1949, when the Dutch formally acknowledged Indonesia's independence. Indonesia was officially recognized as a member of the United Nations in 1950.

\section{Early independence period developments}

Following the war, in the early years after independence, the Indonesian government began to develop a national education system with a focus on providing free universal primary education. From as early as 1945, Islamic educational institutions called pesantren have served as important centers for educating school age students (Bangay, 2005; OECD (Organisation for Economic Co-operation and Development)/ Asian Development Bank, 2015). However, an important declaration of the Sukarno-led government was the right of citizens to receive an education regardless of their ethnic or religious beliefs. During Sukarno's presidency, his government sought to develop an education system that promoted nationalism and that was anti-discriminatory to different ethnic groups and religious beliefs. Sukarno's government oversaw and led the first expansion and development of schools and teacher training programs for the indigenous population of Indonesia. One of Sukarno's most influential government policy decisions was the introduction of the ideology of Unity in Diversity (Bhinneka Tunggal Ika), which is framed by the philosophy of the Five Principles (Pancasila).

The Pancasila philosophy is often viewed as a form of pluralism and call for moderation intended to help create a balance between the interests of individual groups and 
the larger society. These principles have been used to unite Indonesian society by asserting the need for everyone to value a belief in one God, humanitarianism, national unity, democracy, and social justice. The adoption of these policies has had important implications for critical decision-making in government policy regarding religion and language in education. For example, while Indonesia is home to more 600 different ethnic groups that speak more than 700 different languages (Ananta, Arifin, Hasbullah, Handayani, \& Pramono, 2015), Sukarno established Bahasa Indonesia as the national language to be used in formal forums, mass media, governmental and judicial institutions, and in schools. At that time, Bahasa Indonesia was the native language for only about $5 \%$ of the population, but because it has been used as a lingua franca in the archipelago for centuries many different ethnic groups spoke it as a common second language (Rahmi, 2015). Choosing a language spoken by one of the majority ethnic groups did not align with nation's adoption of the Pancasila. The use of Bahasa Indonesia as the national language has been seen as a critical tool in the development of cross-cultural communication and the development of a shared national identity among Indonesian people. The government's respect for diversity and the belief that the needs of individual groups of people need to be balanced with societal needs have been instrumental in shaping public policies aimed at recognizing and respecting Indonesia's diverse population. In subsequent sections, we describe how these standards are incorporated into science teaching and learning today.

\section{Modernizing the education system}

In 1967, following a regime change, Soeharto became the second president of Indonesia. During Soeharto's presidency, from 1967 until his resignation in 1998, he oversaw many initiatives that served to expand opportunities for students to access education. In 1973, the Indonesian Presidential Instruction (INPRES) strategic policy was launched in response to an increased demand for public schooling. Under this program, nearly 40,000 primary school facilities were constructed or repaired to help accommodate the new students enrolling in elementary schools (Suryadarma, Suryahadi, Sumarto, \& Rogers, 2006).

By the late 1980s, Indonesia had achieved free universal primary education and had begun to target the expansion of the basic education program from 6 to 9 years. In 1994, the government established the policy for supporting 9 years of free compulsory education for all students. From 1994 until 2012, the net enrollment ratio for junior secondary schools increased significantly from $50 \%$ to $70 \%$ (Purnastuti, Miller, \& Salim, 2013; Suryadarma et al., 2006). In 2013, the government established universal secondary education that extended compulsory education requirements from 9 to 12 years. While primary and lower secondary education is free, minimal fees are required for students to attend upper secondary schools.

The Indonesian government and the country's science educators are tasked with effectively educating diverse student groups to meet the changing needs of the country, both economically and socially. Science education is expected to play an important role in preparing students to be leaders in STEM fields and to improve the citizens' overall health and scientific literacy. In the following section we briefly introduce the K-20 education system and we describe the K-12 national science curriculum and discuss the challenges of preparing science teachers to effectively teach in so many different contexts. 


\section{Indonesian K-20 education system overview}

In Indonesia, two different ministries oversee the policy and curriculum for all K-12 schools, the Ministry of Education and Culture $(\mathrm{MOEC})^{3}$ is responsible for secular schools, including both general and vocational schools, and Ministry of Religious Affairs (MORA) ${ }^{4}$ is responsible for all religious schools (madrasah) and the State Islamic University system. Graduates from both secular and religious schools can attend any post-secondary public or private secular university, which are all managed by The Ministry of Research, Technology, and Higher Education (MRTHE) ${ }^{5}$

Although all three ministries regulate different educational institutions, they have each adopted a single educational-track structure consisting of 6 years of elementary school, 3 years of junior secondary school, 3 years of senior secondary school, followed by 4 years of tertiary education at the undergraduate university level (6-3-3-4). Recently, education has been extended to also include pre-school education for young learners (see Table 1).

As the K-12 education system is instrumental in preparing the current and future workforce, the government is working for a balance between the academic and vocational education sectors that can support both the development of academic scholarship and research and the practical trades necessary for various industries. Currently, the government is working to more effectively support and regulate tertiary education as well (see Table 2).

Non-profit foundations, known as yayasan, and state-owned enterprises (Badan Usaha Milik Negara [BUMN]), have established many private schools and universities of widely varying degrees of quality. At the tertiary education level, there are significantly more private universities than state-sponsored universities (See Fig. 1).

The source of income for these institutions may come from tuition, funding from private organizations, or governmental support. For private schools in particular, the central government has been providing financial support through school operational funds (Dana Bantuan Operasional Sekolah; MOEC, 2017). Nearly 10\% of elementary schools, $40 \%$ of junior secondary schools, $50 \%$ of senior secondary schools, and $75 \%$ of vocational senior secondary schools are not run by the state (BPS, 2017). Even while the government financially supports many of these private educational institutions, these schools have the authority to employ teachers and to provide education to the public.

Table 1 An overview of the Indonesian K-12 education system

\begin{tabular}{|c|c|c|c|}
\hline Age & School Year & Formal Educational Level & Types of Education \\
\hline $5-6$ & $1-2$ (2 years) & Kindergarten & $\begin{array}{l}\text { General schools (Taman Kanak-kanak-TK) } \\
\text { Islamic schools (Raudatul Athfal-RA) }\end{array}$ \\
\hline $7-12$ & 3-8 (6 years) & Elementary school & $\begin{array}{l}\text { General schools (Sekolah Dasar-SD) } \\
\text { Islamic schools (Madrasah Ibtidaiyah-MI) }\end{array}$ \\
\hline $13-15$ & 9-11 (3 years) & Junior secondary school & $\begin{array}{l}\text { General schools (Sekolah Menengah Pertama-SMP) } \\
\text { Islamic schools (Madrasah Tsanawiyah-MT) }\end{array}$ \\
\hline $16-18$ & 12-14 (3 years) & Senior Secondary School & $\begin{array}{l}\text { General School (Sekolah Menengah Atas-SMA) } \\
\text { Vocational School (Sekolah Menengah Kejuruan-SMK) } \\
\text { Islamic School (Madrasah Aliyah-MA) }\end{array}$ \\
\hline
\end{tabular}

Source: Government Regulation of the Republic of Indonesia No. 17 of 2010 Regarding Educational Management (Peraturan Pemerintah Nomor 17 Tahun 2010 Tentang Pengelolaan dan Penyelenggaraan Pendidikan) 
Table 2 Overview of Indonesian tertiary education system

\begin{tabular}{|c|c|c|c|}
\hline Age & School Year & Formal Educational Level & Types of Education \\
\hline $19-22$ & 4 years & Undergraduate & $\begin{array}{l}\text { Academic education program (Bachelor's degree) } \\
\text { Vocational education program (Diploma degree) }\end{array}$ \\
\hline $22-23$ & 2 years & Graduate & $\begin{array}{l}\text { Academic education program (Master's Degree) } \\
\text { Professional education program } \\
\text { Specialist education program (from Professional } \\
\text { education program) } \\
\text { Applied master's program (from vocational education) }\end{array}$ \\
\hline $24-26$ & 3 years & Post-graduate & $\begin{array}{l}\text { Academic education program (Doctoral degree) } \\
\text { Applied doctoral program (from applied master program) }\end{array}$ \\
\hline
\end{tabular}

Source: Government Regulation of the Republic of Indonesia No. 17 of 2010 Regarding Educational Management

\section{Understanding the impact of historical developments on (science) education today}

We conclude our introduction by highlighting the significant strides of the last three decades, during which time the Indonesian government has expanded access to education and increased school operational funding (Dana Bantuan Operasional Sekolah) such that the vast majority of students are now enrolled in school. This is a considerable feat as Indonesia is currently the fourth most densely populated country in the world, after China, India, and the United States (OECD, 2015).

From 1970 until 2010, the population has doubled from 120 million to over 238 million people-and the population is expected to continue to grow to reach 305 million by 2035 (BPS, 2014). Education statistics from 2016 show universal gross enrolment ratio of schooling in Indonesia for children at the primary (109\%) and junior secondary (90\%) levels and increasing enrollment rates for senior secondary $(80 \%)$ and tertiary (23\%) levels. Compared to any previous period, these data reflect the highest gross enrollment percentage rates ever (See Fig. 2).

This number is only expected to rise as the government is working to fully implement the 2014 legislation increasing compulsory education from 9 to 12 years. Providing an education for 52 million K-12 school children in a country that was devastated just two generations ago by the collapse of the post-war and post-colonial government

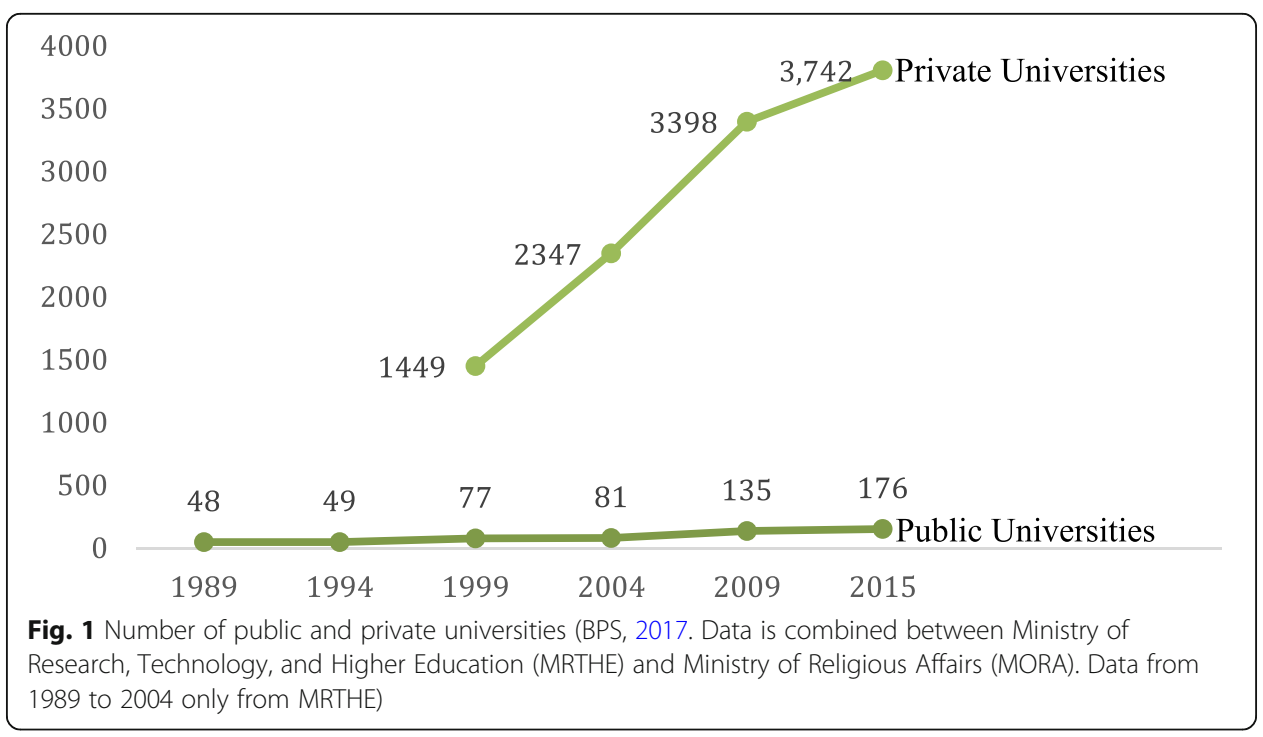




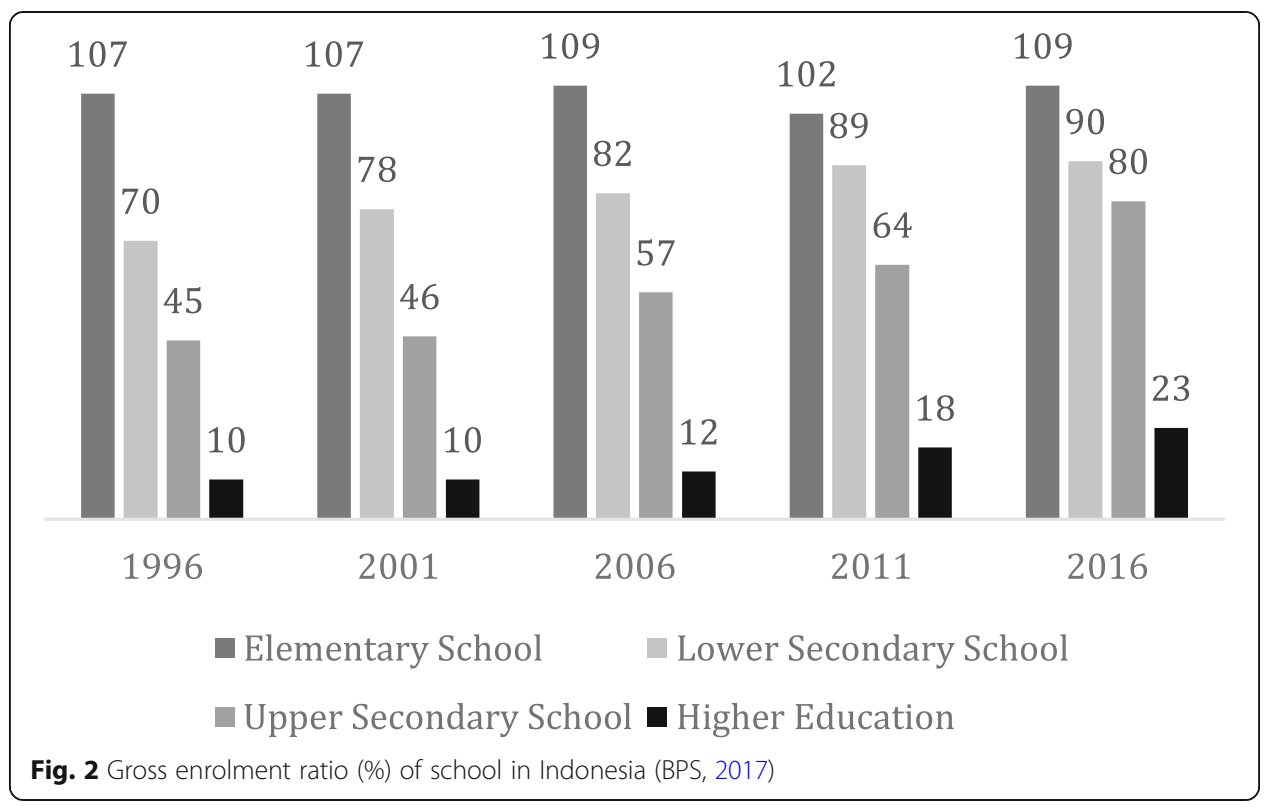

and economy is a remarkable achievement. In the past, the government needed to focus on building capacity for increasing the quantity of students served by the education system. Presently the government is focusing on improving the quality of education for teachers and students. Today, the government and private sector manage are responsible for training and employing about 3.8 million teachers working in more than 300,000 schools (BPS, 2017). That there are more students and even more teachers in the Indonesian education system than there are people in many countries in the world presents a growing challenge for policy makers and government officials developing measures to ensure a high quality education for all students in the country.

\section{Education and science education in Indonesia today}

Currently, initiatives focused on developing the national curriculum, improving teacher preparation and professional development initiatives, and promoting educational research are driving change in the education system and it is having an impact on science teaching and learning as well. In the sections that follow, we describe the present state of the Indonesian education system and by providing examples from science; we offer insights into particular challenges and growth in the field of science education in Indonesia today. Specifically, we describe the development of the national science curriculum and science textbook development and we provide context for understanding some of the challenges facing teachers when attempting to employ a standard curriculum in so many different kinds of schools, with diverse students, and in widely varying learning environments.

\section{Indonesian national curriculum overview}

The Indonesian government is highly centralized, giving the Ministry of Education and Culture full authority to design the structure and select all components to be included in the curriculum. Traditionally the MOEC has managed the educational system with a 
top-down approach, sending new initiatives from the central level to local schools and teachers. However, in 1994 the government took the first steps towards educational decentralization by encouraging schools to develop courses that were relevant to their local social communities and environments (Bjork, 2004). In 1999, the government implemented a more expanded decentralization policy that allowed local education authorities, schools, and teachers a greater autonomy and responsibility (Heyward, Cannon, \& Sarjono, 2011). Part of this plan included the development of a national competency-based curriculum (Kurikulum Berbasis Kompetensi $[\mathrm{KBK}]$ ) designed to emphasize students' abilities to respond to global challenges and rapid developments in science and technology. Enacted nationally in 2004, the KBK outlined important learning outcomes for students and encouraged teachers to adapt instruction of this content to their local contexts.

In 2006, the KBK curriculum was revised to become a school-based curriculum (Kurikulum Tingkat Satuan Pendidikan [KTSP]), providing even greater autonomy to local education authorities and teachers (Parker, 2017). The new KBK encouraged educators to design lesson plans, instructional materials, and assessment instruments based on the national standards. Most recently, in 2013, the KBK was revised once more to improve the quality of the national education system. Specifically, the revisions sought to tackle three specific concerns: preparing Indonesia's huge youth population for future labor markets, strengthening students' awareness and appreciation of social-cultural and environmental issues in Indonesia, and improving Indonesian students' performance on international comparative assessments.

\section{Current national curriculum structure}

According to the 2013 curriculum structure, senior secondary schools should offer 18 subjects divided into three different groups (see Table 3). These groups are categorized by general content and are provide schools a general guideline for determining what content needs to be taught at each grade level.

All students are required to take all six courses in Column A, which includes government-approved courses related to language, mathematics, history, civics, and religion. The Indonesian government formally recognizes six different religions (Islam, Christianity, Catholicism, Buddhism, Hinduism, and Confucianism). Students should choose the religion

Table 3 List of subjects offered in Indonesian schools

\begin{tabular}{|c|c|c|}
\hline Group A & Group B & Group C \\
\hline \multirow{3}{*}{$\begin{array}{l}\text { 1. Religious Education: Islam/Christianity/ } \\
\text { Catholicism/Hinduism/Buddhism/Confucianism } \\
\text { 2. Civic Education } \\
\text { 3. Indonesian Language (Bahasa Indonesia) } \\
\text { 4. Mathematics } \\
\text { 5. Indonesian History } \\
\text { 6. English }\end{array}$} & \multirow{3}{*}{$\begin{array}{l}\text { 7. Arts and Culture } \\
\text { 8. Physical, Sports, and } \\
\text { Health Education } \\
\text { 9. Heritage Workshops }\end{array}$} & $\begin{array}{l}\text { 10. Biology } \\
\text { 11. Physics } \\
\text { 12. Chemistry }\end{array}$ \\
\hline & & $\begin{array}{l}\text { 13. Geography } \\
\text { 14. Economics } \\
\text { 15. Sociology }\end{array}$ \\
\hline & & $\begin{array}{l}\text { 16. English } \\
\text { 17. Additional Foreign Languages } \\
\text { (Arabic, Mandarin Japanese, } \\
\text { Korean, German, and French) } \\
\text { 18. Anthropology }\end{array}$ \\
\hline
\end{tabular}


courses based on their individual religious beliefs: Muslim students take Islamic education courses, Buddhist students take Buddhist education courses, and so on.

Courses in Column B are intended for enrichment and include a special focus on arts and culture. This content is often taught using a workshop format in which students learn about and practice different forms of art associated with local traditions from specific ethnic and cultural groups. For example, students may learn about and practice traditional dance, learn to make and play traditional musical instruments and make handicrafts, or learn to speak local ethnic languages.

Students are expected to select courses from Columns A and B that reflect their own religious, ethnic, cultural, and linguistic heritage, which allows students them to learn about and celebrate diverse ways of being Indonesian. For example, even though nearly 87\% of the population identifies as Muslim (BPS, 2010), all minority religious groups are provided the same rights to practice and promote their religions-including in schools. This means that even though students in both secular and religious schools follow the same general curriculum, respect for diverse religious observance is encoded in the national curriculum for all subjects, including in the teaching and learning of science. In addition to the specified courses in Columns A and B, all students at the elementary and junior secondary levels need to take these courses. However, English and Indonesian history are not compulsory subjects for elementary school students.

Additionally, students at the senior secondary level should select a cluster of courses from Column C. This column is divided into three clusters, or "tracks," to prepare students to have a concentration in one of three main areas: science, social science, or humanities. For example, students who select the social sciences track take coursework in geography, economics, and sociology, and students who select the humanities track study an additional foreign language and take classes in anthropology and culture. Finally, students who choose the science track will take advanced coursework in biology, physics, and chemistry. Further, elementary and junior secondary school students also learn science using an integrated content curriculum rather than studying individual subjects such as biology or chemistry.

\section{General science curriculum}

Prior to the senior secondary level, all elementary and junior secondary school students learn basic science. However, at these levels, science is taught as an integrated and thematic subject with no distinct separation between physics, chemistry, and biology content. At the elementary level, science is taught three times per week with total allocation time of about 105 min per week. At the junior secondary level, students take five science classes per week with an allocation time of about 200 min per week. For students who select the science track at the senior secondary level, each science subject is taught independently with a time allocation of about $135 \mathrm{~min}$ per subject each week. For example, each week, students take three classes each of biology, physics, and chemistry with a total allocation of about $405 \mathrm{~min}$ per week. In addition to this lecture time, teachers at the senior secondary level can opt to teach two additional classes per week for each subject. This time period can be used for practical work, demonstrations, and examinations. Below we share details about the senior secondary level biology curriculum to provide more understanding of the depth and breadth of the content Indonesian students study when taking courses in the science track. 


\section{Senior secondary biology curriculum}

During senior secondary school, students in Grades 10-12 take biology each year and are expected to learn a wide range of content. As shown in Table 4, students are first introduced to the definition and scope of biology as a study of living things.

In the first year, students focus on classification of organisms, understanding the flow of energy in ecosystems, and learning about environmental topics such as climate change. In Grade 11, the discussion is narrowed to focus on form and function of plants and the human body, with a particular focus on examining the different body systems. Finally, more complex topics such as metabolism, evolution, genetics, and biotechnology are taught in Grade 12.

\section{Application of cross-cutting curriculum standards to science content}

While the organization of topics for each subject is similar to previous versions of the curriculum, the 2013 curriculum also requires that science teachers integrate general and scientific process skills with content learning objectives as part of their general teaching and learning activities. To do so, science teachers need to pay attention to two main categories of competencies, referred to as the Main Competencies (Kompetensi Inti $[\mathrm{KI}]$ ) and Basic Competencies (Kompetensi Dasar [KD]). Teachers are required to integrate these two sets of competencies within their subject matter curriculum.

For example, the Main Competencies (see Table 5) target the development of students' spiritual, social, psychomotor, and cognitive domains and are applicable to all subject areas at every grade level (MOEC, 2016a).

In addition to these four overarching Main Competencies, teachers should also incorporate Basic Competencies that are specific for each subject and grade level. The Basic Competencies target cognitive and psychomotor domains related to specific subject matter and also emphasize the use of student-centered, constructivist, and active learning strategies. As such, teachers are expected to engage students in active learning and to also employ authentic assessments designed to measure students' achievement in each competency and to assess students' content understanding.

The Main and Basic Competencies outlined in the new curriculum provide teachers with content objectives and suggestions about teaching strategies, instructional materials, and assessment methods aimed to support teachers as they design their lessons.

Table 4 Biology topics for senior secondary school level

\begin{tabular}{lll}
\hline Grade 10 & Grade 11 & Grade 12 \\
\hline - What is biology? & - Structure and function of plant & - Plant and animal growth \\
- Indonesian biodiversity & and animal cells & - Enzyme, photosynthesis, \\
- Classification of organisms & - Plant and animal tissue & cellular respiration \\
- Characteristics and roles of & - Human body system: skeleton & - Structure and function of \\
viruses, archaebacteria, eubacteria, & and muscle system, circulatory & genetic materials (DNA, RNA, \\
protista, fungi, plants, and & system, digestive system, respiratory & genes, and chromosomes) \\
invertebrates in human life & system, coordination system, & and protein synthesis \\
- Ecosystem, energy flow in ecosystems, & reproductive system, and & - Cell division (plant and \\
biogeochemical cycles, and interactions & immune system & animal) \\
within the ecosystem & & - Mendelian inheritance \\
- Environmental and climate change and & & - Mutation \\
waste recycling & & - Evolution \\
& & - Biotechnology \\
\hline
\end{tabular}

Source: MOEC (2016b) 
Table 5 Main competencies of the 2013 Indonesian National Curriculum

\begin{tabular}{|c|c|c|c|}
\hline Spiritual & Social & Cognitive & Psychomotor \\
\hline $\begin{array}{l}\text { Refers to having } \\
\text { students understand } \\
\text { and practice religious } \\
\text { beliefs and values in } \\
\text { their daily lives }\end{array}$ & $\begin{array}{l}\text { Refers to shared social and } \\
\text { cultural values, such as } \\
\text { honesty, self-discipline, } \\
\text { responsibility, social } \\
\text { awareness, cooperation, } \\
\text { and tolerance }\end{array}$ & $\begin{array}{l}\text { Derived from revised } \\
\text { Bloom's taxonomy, } \\
\text { emphasis in science is on } \\
\text { having students' analyze, } \\
\text { evaluate, and create } \\
\text { representations of } \\
\text { understanding }\end{array}$ & $\begin{array}{l}\text { Refers to the need to have } \\
\text { students develop their } \\
\text { process skills, } \\
\text { communication skills, and } \\
\text { problem-solving abilities }\end{array}$ \\
\hline
\end{tabular}

Source: MOEC (2016a)

For example, Table 6 offers an example of the Basic Competencies developed for the Senior Secondary School (SSS) Biology Curriculum.

Table 6 shows that at the secondary school level, teachers are tasked to address 70 basic competencies related to biology. This is in addition to the Main Competencies outlined previously and the individual subject matter learning objectives for each subject and grade level. So teachers must cover not only a large number of biology-related competencies, but they need to also work to involve students in activities focused on analyzing and observing the structure and function of different kinds of cells and components of cells.

Actively engaging students in science learning rather than relying on teacher-directed instruction can be rather challenging, as certified teachers in public schools are required to teach a minimum of 24 classes per week. At the secondary school level, this is the equivalent of 18 instructional hours. While this number may seem low, meeting this minimum requirement is actually quite difficult. For one, teachers can only teach courses for subjects for which they are certified, and they can only offer the courses stipulated in the curriculum. A typical Grade 10 biology teacher should offer four biology classes per week to each group of students. To meet the 24-class requirement, a teacher would need to provide instruction for six different groups of biology students. Typically, there are 36 or more students in each group. This means one teacher will typically instruct about 200 students every week.

For teachers who are tasked with employing student-centered learning strategies, it can extremely difficult to manage such a large number of students. Even so, teachers and students feel a great deal of pressure to meet these requirements, as both the Main and Basic Competencies are referenced by the MOEC when writing national examinations.

Table 6 Example of Biology basic competencies for senior secondary school

\begin{tabular}{|c|c|c|c|}
\hline Grade & Cognitive Competencies & Psychomotor Competencies & $\begin{array}{l}\text { Total of Basic } \\
\text { Competencies }\end{array}$ \\
\hline 10 & $\begin{array}{l}\text { Analysing the various levels of } \\
\text { biodiversity in Indonesia and how } \\
\text { to preservation it }\end{array}$ & $\begin{array}{l}\text { Presents data about biodiversity in } \\
\text { Indonesia and proposed an appropriate } \\
\text { conservation method }\end{array}$ & 22 \\
\hline 11 & $\begin{array}{l}\text { Analysing the structure and function } \\
\text { of plant cell, tissue, and organ }\end{array}$ & $\begin{array}{l}\text { Observing the structure of plant cell, } \\
\text { tissue and organ }\end{array}$ & 28 \\
\hline 12 & $\begin{array}{l}\text { Describing the effect of internal and } \\
\text { external factors on the growth and } \\
\text { development of the organism }\end{array}$ & $\begin{array}{l}\text { Making an experiment report about the } \\
\text { influence of external factors on the plant } \\
\text { growth and development }\end{array}$ & 20 \\
\hline
\end{tabular}


These exams are designed to assess cumulative learning by students at the end of both junior and senior secondary school, and students' scores have an impact on their tertiary enrollment opportunities and also on the reputation of a school. Thus, the curriculum changes are part of an overall move towards teacher and student accountability. While these kinds of policies can effect positive changes in schools, they require effective teacher preparation. Improving the standards for preparing and certifying teachers is a critical for improving the overall quality of education for all students in Indonesia. In the sections that follow, we describe regulations and practices associated with science teacher education and we highlight practices intended to improve teachers' content knowledge and instructional strategies in science.

\section{Science teacher preparation}

In an effort to attract more senior secondary school graduates to consider teaching as a post-secondary career pathway, the government enacted a new Teacher Law (UU No. 14) in 2005 that increased the standard salary for all people entering the teaching profession. To help enhance the perception of teaching as a professional career, the new law required that all teachers at all school levels should receive a bachelor's degree in an academic subject and complete a teacher certification program. This policy has significantly increased post-secondary enrollment in national teacher education institutions (TEI). ${ }^{6}$ TEIs consist of both private and public institutions. There are two kinds of public TEIs. The most prestigious are universities that were historically founded as normal universities or teacher training colleges that focused solely on teacher preparation. However, today all of these universities have expanded their programs to provide both teacher education programs and additional programs of study in undergraduate or graduate degree programs in areas such as sciences, engineering, and humanities. For example, the State University of Malang (Universitas Negeri Malang), which was a top-ranked teacher training college, has expanded to include many other programs.

In addition, the second type of public TEI are general universities that have historically included a small teacher education program (Fakultas Keguruan dan Ilmu Pendidikan). In addition to public TEIs, there have been an ever-increasing number of private TEIs being opened that focus solely on teacher preparation. ${ }^{7}$ These private TEIs are generally privately owned and managed and they tend to be much smaller than the public TEIs. Today, teacher preparation is dominated by these smaller private TEIs. Currently, the MRTHE oversees about 380 private TEIs and only 40 public TEIs (MRTHE, 2016a).

\section{Gaining admittance to public and private TEls}

There are no specific requirements necessary for enrolling in a pre-service teacher education program in a public TEI. However, prospective teachers can gain entrance to a public university via either a national selection process or a local selection process. For the national selection process, prospective teachers can apply via two pathways, by evaluation of academic records from senior secondary school ${ }^{8}$ or by sitting for the national college entrance exam, ${ }^{9}$ which is offered once per year. Students can apply for early admission based on their academic records. If they fail to gain admission via this route, they can then sit for national college entrance exam. Students who are not 
admitted based on their academic record or test scores have a third possible route for becoming a teacher: They may gain admittance via independent examination processes established by individual universities. This last process mentioned is the one used by private TEIs (MRTHE, 2017).

Prospective teachers who seek admission via the national college entrance exam score can study for and take a qualification exam in one or two of the subject areas shown in Column $\mathrm{C}$ of Table 3. This column includes coursework in the sciences, social science, or humanities. This means that even if a high school student selects the science track for study in senior secondary school, when taking the exam for becoming a prospective teacher, a student can choose to take the national exam for courses in any of the three tracks in Column C. For example, a humanities-track student could choose to sit an exam in science in an effort to qualify for a position as a prospective teacher in a TEI. This means that is it possible for a student who studied primarily humanities in high school can become a science teacher and enter a science teacher education program even without having studied science intensively in secondary school. However, this route is very difficult and not common. No matter the route taken, for students seeking regular admission entrance to either a public or a private TEI, exam scores are the main criterion for selecting prospective teacher candidates.

To improve the quality of teacher education programs, the MRTHE provides regulations for how TEIs should run all teacher preparation programs. The regulations stipulate required national minimum standards, including coursework and experience that enable students to meet all competencies and cover all curriculum content and provide guidelines for structuring all teaching and learning activities and evaluation procedures. In addition, the regulations set standards for requiring TEIs to employ faculty with specific qualifications, such as advanced degrees and teaching experience. The regulations also stipulate standards for physical facilities for the TEIs, such as classrooms and laboratories. Finally, regulations are set to oversee management and financial matter such as tuition costs.

\section{Completing initial certification requirements}

Prospective teachers must complete bachelor's degree coursework at one of the three TEIs described above before beginning the process for receiving certification. Bachelor's degree $(\mathrm{S} 1)^{10}$ programs for pre-service teachers generally require 4 years of coursework, the equivalent of 140-160 credit hours, in both subject matter and pedagogical content. Prospective teachers also have opportunities to practice their teaching skills via micro-teaching programs and practicums teaching at local schools near the end of their coursework. The teaching practicum is generally quite short, lasting between 8 and 10 weeks. During this time, prospective teachers design and teach four lessons to one or two classes. At the completion of the program, all graduates are eligible for employment in either a public or private school. The general mechanism of teacher selection and recruitment showed in Fig. 3.

Completion of the program, however, does not coincide with professional certification. After working for a minimum of 3 years in either a public or private school, teachers can apply for professional certification. Both private and public school teachers are eligible to 


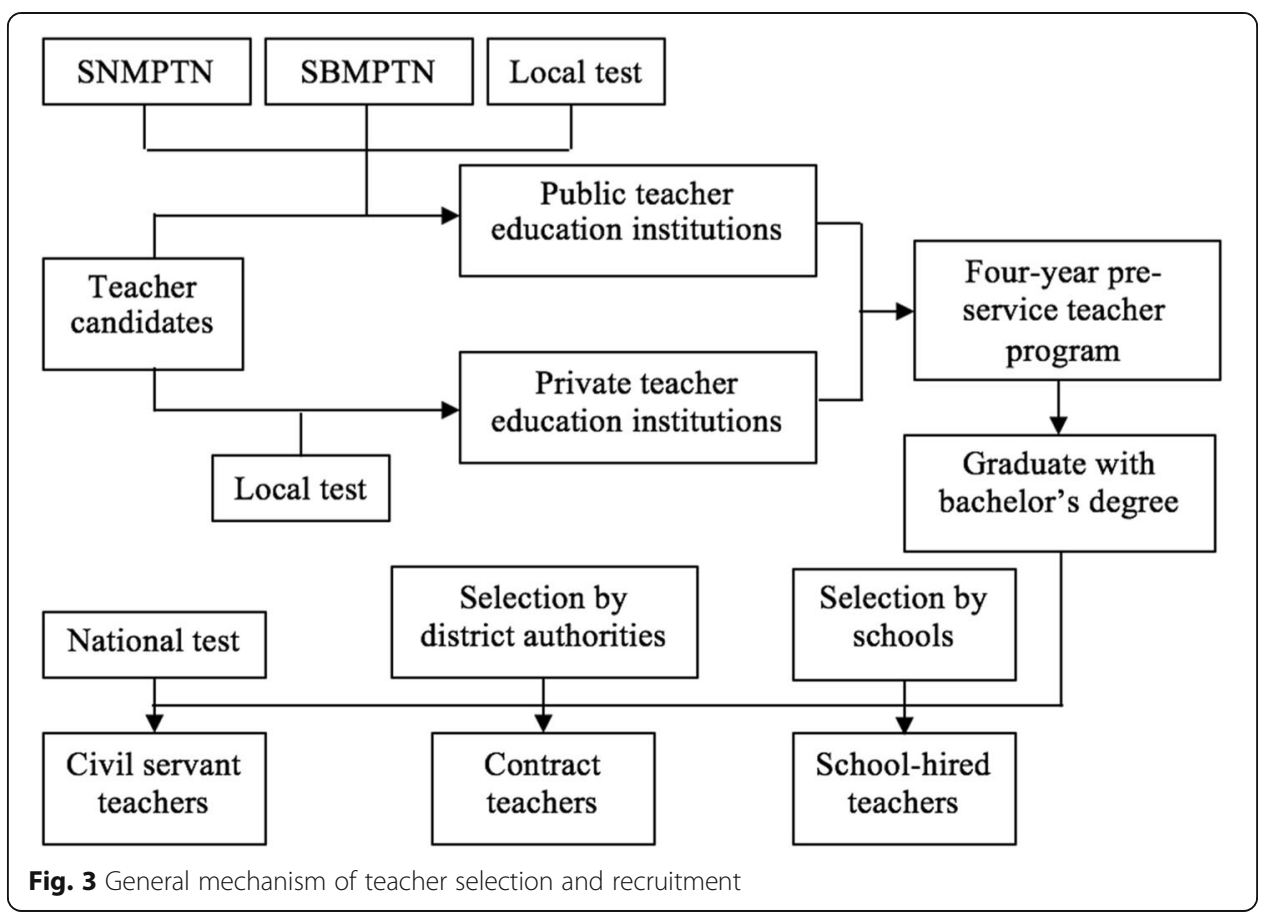

apply for this professional teaching certificate. In the following sections, we describe the general teacher hiring process and professional certification process.

\section{Teacher hiring process for public schools}

Following graduation from a bachelor's degree program, prospective teachers who have completed all requirements for initial certification can begin a process to be selected for employment. With this initial teaching certificate, candidates are eligible to be hired as a teacher in either public or private schools. Regardless of where or how K-12 educators are employed in Indonesia, all educators in public and private schools are managed by both the MOEC and MORA. As such, all educators have to be formally registered as teachers and must meet the minimum national requirements for employment, which include completing a bachelor's degree, submitting documentation demonstrating the completion of a teaching practicum, and evidence of having passed the national teaching exam with the minimum required score. In the sections that follow, we describe the hiring process for public schools.

\section{Civil servant teaching positions}

To be selected, prospective teachers face considerable competition from large numbers of recent graduates. Because public teaching positions in Indonesia are civil-servant jobs, they provide job security that is not easy to find in other private job sectors. To become a civil servant teacher, candidates must pass the national teacher selection exam with a high score. Civil servant exams are held at different times in different provinces, and the number of positions to be filled each year is based on regional needs. To calculate how many teachers will be hired at the national level, regional authorities first identify the number of teachers needed for each school level and 
content area in their region. These regional quotas are then used to determine the number of teachers who can be hired nationally. For example, in 2018, the central government announced that around 100,000 new teachers would be hired to help reduce the current teacher shortage.

To be considered for one of these positions, candidates must register online and submit documents as evidence that they meet all administrative requirements for being hired if selected. The national teacher exam takes places in two stages. In the first stage, all candidates simultaneously sit for a national computer-assisted exam that assesses teachers in three main domains: personal characteristics, general intelligence, and a general exam covering topics related to national history, constitutional law, and civics. Each domain requires candidates to meet a minimum passing grade to continue to the second stage. In the second stage, prospective teachers have content-based exams and a general interview. For example, candidates applying for a biology teacher position will take a computer-assisted test managed by the regional staffing office to assess their biology subject matter knowledge. Both the examination and hiring process for civil servant positions are coordinated via the central government and local provincial authorities seeking teachers for their schools. Each year, there are a limited number of positions made available for each grade level, subject area, and province. As a result, the process for becoming a certified public school teacher is incredibly competitive.

\section{Non-civil servant teaching positions}

Candidates who do not perform well on the national teacher exam may seek employment through non-civil-servant teaching positions. In these cases, teachers are hired on either short-term contracts or hired to teach on yearly contracts in public and private schools. Some public schools employ contract teachers to meet shortages in teaching staff. Contract-teacher positions are available in both public and private schools. However, this position is less prestigious than a civil-servant teaching position, and the salary for contract teachers is generally lower. Civil-servant teachers are paid directly by the government, but contract-teacher salaries are paid by regional offices or schools, whose teaching salary budgets depend heavily on school operational funds provided by the government and students' tuition. As a result, these teachers are paid less, but contract teachers working in both public and private schools have the same opportunities to receive professional teaching certification from the government.

The government has expanded options for preparing and certifying teachers beyond the civil servant system because there are currently not enough teachers to support the huge number of students currently enrolled in K-12 schools. Varied routes for becoming a teacher have allowed for more prospective teachers to complete their education and certification processes. This means the government can ensure a basic level of teacher quality in schools, which is critical for Indonesia's future. These alternative route programs have helped to expand efforts to prepare a large teacher workforce. However, the government recognizes that to maintain a high level of teacher quality, post-certificate teachers need to continuously engage in professional development programs aimed at improving and developing teachers' classroom practices. In the section that follows we describe recent revisions to the certification process that has evolved in an effort to not only prepare large numbers of teachers, but to also prepare high quality teachers. 


\section{Professional teacher certification process}

After completing several years of teaching and meeting many additional requirements, teachers can apply for permanent professional teaching certification. The government established this new professional license for in-service teachers in 2007. The professional certification requires teachers submit a portfolio record of accomplishments from their teaching experience. The portfolio should include training and conference certificates, published papers, awards, examples of exemplary lessons and students' work samples, and organizational experience. The portfolio is reviewed by selection committees from TEIs using a rubric for assigning points for meeting criteria in key areas specified by the MRTHE. If the minimum passing grade is achieved, the teacher will receive official professional certification from the MOEC. This route to achieve professional certification is preferred by teachers. Until 2012, teachers who were unable to meet the minimum requirements for the portfolio assessment could revise and resubmit their materials for the following assessment period or they could choose another route for professional certification through the Teacher Professional Education and Training (Pendidikan dan Latihan Profesi Guru [PLPG]) program.

In 2012, the MOEC passed Act No. 5, which abolished the portfolio route and established that all professional certification be completed via the PLPG. The PLPG procedures for meeting certification requirements differ from the original route, especially with regard to the mechanism for developing and evaluating the teacher portfolio system. Rather than complete the portfolio, teachers attend a series of two-week professional development programs designed and implemented by TEIs. In coordination with the MOEC, educators in the PLPG provide teachers with professional development sessions that emphasize improving teachers' pedagogical content knowledge and their classroom teaching practice.

At the completion of the PLPG program, teacher performance is evaluated in four main areas: knowledge of pedagogy, personal interactions, social interactions, and professionalism. After completing a computer-assisted or paper-based test, teachers must receive an evaluation of "good" in all categories and must score a minimum of 80 points on the teachers' competency test. Teachers who do not pass the assessment process can retake the test four times within 2 years. Teachers who become certified through this process will receive a professional teacher's salary from the government until their retirement-which is similar to being hired in a civil servant position. This salary is typically double the salary made by non-certified teachers.

In 2017, to improve the quality of the teaching certification process, the government introduced a new policy that replaced the PLPG with the Teacher Professional Education (Pendidikan Profesi Guru [PPG]). The PPG program can be conducted by all accredited TEIs that have received official permission from the government. The PPG program is designed to be completed by in-service teachers over a one-year period during two semesters. During this time, teachers complete 36 to 38 credits of coursework. Teachers eligible to participate in the PPG program are those who have more than 5 years of teaching experience and who have passed general intelligence, content, and English exams. The PPG program integrates theoretical knowledge and practical teaching skills. Teachers engage in workshops to develop teaching materials, engage in peer-teaching activities, conduct school observations, and implement lessons designed to promote group reflection on best practices. The program also trains teachers to 
become more skilled in conducting classroom action research. At the end of the program, teachers must pass an exit exam. After completing the exam, teachers receive a professional teaching certificate (MOEC, 2016c).

The government recognizes the need to provide teachers with high quality curriculum resources, such as textbooks. In the next section, we discuss textbook development in Indonesia and describe some of the important organizations working to provide on-going professional support and development for science teachers. Specifically, we highlight examples from biology textbooks to show what kinds of science education resources are available to help teachers and students meet the Main and Basic Competencies and the national science content standards. We also introduce professional teaching organizations and discuss the ways in which these groups seek to promote pedagogical and theoretical advancements in education and science education for Indonesian teachers and teacher educators.

\section{Science textbook development}

The Indonesian government has two main mechanisms for providing textbooks to support curriculum implementation. First, the government may approve textbooks developed by various authors and adopt them for publication as national textbooks. Alternatively, a non-government publishing company can develop a textbook using the national standards. For example, all biology textbooks, published by either government or private entities, must include instructional activities focused on observation, simple experiments/demonstrations, and inquiry-based investigations designed to help teachers and students achieve both Basic and Main Competencies in the curriculum.

There are seven non-governmental publishers (Yudhistira Galia Indonesia, Tiga serangkai, Erlangga, Esis, Gramedia Widiasarana Indonesia, Intan Pariwara, and Yrama Widya) that actively contribute to publishing more than 15 biology textbooks for each grade. However, the textbooks generally share common features, such as structure and content arrangement, as the authors all use the same criteria described by the MOEC for writing textbooks. The criteria require that textbooks include a generalized content structure and organization and offer learning and teaching activities within the text. In addition, the guidelines provide clear instructions about layout, language, references, and the requirement to include detailed information about the people involved in the textbook production (the authors, editors, illustrators, reviewers, and publishers). Thus, there is limited room for variation. In addition, the authors are required to represent diverse academic backgrounds and professions, such as science teachers, university content lecturers, teacher educators, and researchers (MOEC, 2016d).

The textbooks are usually revised following the enactment of new educational standards in the national curriculum. The most recent textbooks have been designed to support teachers and students to achieve the 2013 national science competencies. When covering any topic, textbooks should include three main parts: the content learning objective, a theoretical description of the science content and process skills to be learned, and detailed procedures for conducting any activities. In addition, textbooks often include illustrations, diagrams, and photographs to help students easily understand concepts and conduct experiments. For example, an instructional activity in Grade 12 biology focused on learning about the growth and development of organisms asks students to observe seeds from dicotyledonous and monocotyledonous plants, to 
label and describe each part of the seed, and to identify similarities and differences between them. If teachers have laboratory materials and equipment available, students can follow learning activities outlined in the textbook. However, if there are no supporting laboratory tools and materials, they can modify or make a different type of activity targeting the outlined subject competencies. However, in order to successfully make use of these materials to design and implement student-directed lessons, teacher education programs need to adequately prepare new science teachers to meet these challenges.

\section{Science teacher professional development}

To support teachers to be successful in implementing target practices, the government encourages certified teachers to engage in on-going teacher professional development (TPD) programs. Participation in these TPD programs is required in order for teachers to retain their certification. Three different institutions are tasked with organizing TPD for teachers: the government, national teachers' organizations, and local teachers' associations.

\section{Governmental TPD}

The most commonly employed TPD strategy used by the government is the training of trainers (ToT) model (Widodo \& Riandi, 2013), which has been widely implemented since the introduction of the revised 2013 curriculum. Using this model, schools delegate one or a small number of representative teachers to attend a TPD program. Programs are typically offered in large or capital cities within each province so teachers from rural areas need to travel to a central point to receive instruction (Sari, 2012). After receiving training, the teachers return to their school site and then train their fellow teachers using the same materials. The framework for the TPD structure was adapted from a 2009 World Bank program called Better Education Through Reformed Management and Universal Teacher Upgrading, which provides TPD modules linked to teachers' progressive development over time, helping to ensure that teachers have an ongoing in-service training structure that supports their career trajectory.

The government also cooperates with local teacher communities called Subject-Based Teacher Groups (Musyawarah Guru Mata Pelajaran [MGMP]), who organize empowering programs in local contexts. These MGMP empowering programs are designed to empower teachers by involving them in various activities such as pedagogy workshops, microteaching activities, classroom observation and reflection, and action research (Soebari \& Aldridge, 2016). With around 15,000 MGMPs in Indonesia, the program is expected to have a significant impact on teacher practices in local communities (The World Bank. 2010).

\section{TPDs of the national teacher organization and local teacher associations}

In addition to official government programs, national teacher organizations and local teacher associations also provide TPD. Currently, there are two main national teacher organizations that actively provide TPD programs: the Indonesian Teacher Union (Persatuan Guru Republik Indonesia [PGRI]) and the Indonesian Teacher Association 
(Ikatan Guru Indonesia [IGI]). Some examples of the TPD provided by PGRI include the establishment of the PGRI Smart Learning Center (https://www.pgrislc.com) and programs to improve teachers' writing skills and research competencies. Further, the TPD programs of IGI facilitate teacher's abilities to integrate information and communication technology into daily teaching activities as well as enhance teachers' scientific literary practices.

To promote local TPD programs, some science education faculty from TEIs collaborate with science teachers to establish regional professional associations. These local teacher associations organize regular workshops and seminars and offer an effective forum to disseminate research findings and share ideas between science teachers and science teacher educators to solve important issues related to the teaching practices in schools. Besides these options, MGMPs in each district also frequently arrange TPD programs to improve member capacity by inviting trainers from local universities or teachers from neighboring schools to share skills, to create lesson plans and teaching materials, and to learn about new instructional strategies. While national organizations and local associations dedicated to science teaching are instrumental in improving science education, there are also many national teacher organizations and TEIs that play similar roles in conducting and sharing research in science education in Indonesia. Teachers and researchers have a rich environment for continuous professionalization.

\section{Professional organizations and journals}

The passage of the Teacher Law (UU No. 14) in 2005 required that all teachers should become members of a professional organization. The main objectives of this law were to help develop teachers' professionalism, to improve teacher competence and capacity, to support teachers' career development, and to provide a platform for teacher advocacy. This law required that the government facilitate the formation and development of teacher organizations for different groups of teachers. The oldest such teacher organization is the PGRI, which was first established by congress in November 1945, shortly after the proclamation of Indonesian independence. The PGRI provides support for teachers at all school levels and employment statuses. Another important national teacher organization is the IGI, formed in 2009 with the main goal of for improving teacher competencies by implementing various learning innovation programs. The PGRI and IGI have working groups at the national, provincial, and district levels. The PGRI and IGI also distribute scientific publications, provide funding to support research collaborations, and host domestic and international conferences,

In addition to these two groups, the TEIs are leaders in supporting and conducting educational research and disseminating scientific publications in Indonesia in the field of education. Recently, TEIs has been working with the MRTHE to increase the number and quality of educational research publications. In 2016, the MRTHE initiated the development of a web-based research information system named the Science and Technology Index (Sinta; (http://sinta2.ristekdikti.go.id/) to help measure the performance of Indonesian researchers, particularly in higher education institutions. The Sinta database record in 2018 shows that there are more than 2000 journals 
listed from over 200 different institutions and professional associations in Indonesia. Some of these journals are also part of the TEIs' Open Journal System. This open source system enables TEIs to organize and publish online their academic journals and improve their accessibility for national and international scholars.

TEIs mainly support publications for and from teachers, graduate students, and science-teacher educators. Some of the education and science education journals published by TEIs are shown in Table 7.

The first four journals listed in Table 7 are solely focused on science education. Of these journals, the Indonesian Journal of Science Education (Jurnal Pendidikan IPA Indonesia) is the only journal indexed by Scopus with an $\mathrm{H}$-index of 20. The journal was first published in 2012 with an issue every April and October. In 2018, the publication was increased to four times a year (March, June, September, and December) with around 20 articles in every issue. This journal is affiliated with science education faculty at the State University of Semarang (Universitas Negeri Semarang) in collaboration with the Indonesian Society for Science Educators (Perkumpulan Pendidik IPA Indonesia). Six other journals, including the Journal of Education and Learning and the Journal of Education and Instruction, publish articles covering general education and learning contexts including science, mathematics, social science, language and humanities, and environmental studies. These journals are all examples of advances being made in the realm of educational research and scholarship in general and in science education specifically.

Table 7 Education and science education journals in Teacher Education Institution (TEI)

\begin{tabular}{|c|c|c|c|}
\hline No & Name of Journal & Affiliation & Website \\
\hline 1 & $\begin{array}{l}\text { Indonesian Journal of Science Education } \\
\text { (Jurnal Pendidikan IPA Indonesia) }\end{array}$ & $\begin{array}{l}\text { State University of Semarang } \\
\text { (Universitas Negeri Semarang) }\end{array}$ & $\begin{array}{l}\text { https://journal.unnes.ac.id/ } \\
\text { nju/index.php/jpii }\end{array}$ \\
\hline 2 & $\begin{array}{l}\text { Journal of Science Education Research } \\
\text { (Jurnal Penelitian Pendidikan Ipa/ JPPIPA) }\end{array}$ & $\begin{array}{l}\text { State University of Mataram } \\
\text { (Universitas Negeri Mataram) }\end{array}$ & $\begin{array}{l}\text { http://jppipa.unram.ac.id/ } \\
\text { index.php/jppipa }\end{array}$ \\
\hline 3 & Journal of Science Learning/ JSL & $\begin{array}{l}\text { Indonesia University of Education } \\
\text { (Universitas Pendidikan Indonesia) }\end{array}$ & $\begin{array}{l}\text { http://ejournal.upi.edu/ } \\
\text { index.php/jslearning }\end{array}$ \\
\hline 4 & $\begin{array}{l}\text { Journal of Research and Science Learning } \\
\text { (Jurnal Penelitian dan Pembelajaran IPA) }\end{array}$ & $\begin{array}{l}\text { Universitas Sultan Ageng } \\
\text { Tirtayasa. }\end{array}$ & $\begin{array}{l}\text { http://jurnal.untirta.ac.id/ } \\
\text { index.php/JPPI }\end{array}$ \\
\hline 5 & Jurnal Cakrawala Pendidikan. & $\begin{array}{l}\text { State University of Yogyakarta } \\
\text { (Universitas Negeri Yogyakarta) }\end{array}$ & $\begin{array}{l}\text { https://journal.uny.ac.id/ } \\
\text { index.php/cp }\end{array}$ \\
\hline 6 & $\begin{array}{l}\text { Journal of Education and Instruction } \\
\text { (Jurnal Pendidikan dan Pembelajaran/JPP) }\end{array}$ & $\begin{array}{l}\text { State University of Malang } \\
\text { (Universitas Negeri Malang) }\end{array}$ & $\begin{array}{l}\text { http://journal.um.ac.id/index. } \\
\text { php/pendidikan-dan- } \\
\text { pembelajaran/index }\end{array}$ \\
\hline 7 & $\begin{array}{l}\text { Journal of Mathematics and } \\
\text { Science Teaching } \\
\text { (Jurnal Pengajaran Matematika dan IImu } \\
\text { Pengetahuan Alam/JPMIPA) }\end{array}$ & $\begin{array}{l}\text { Indonesia University of Education } \\
\text { (Universitas Pendidikan Indonesia) }\end{array}$ & $\begin{array}{l}\text { http://journal.fpmipa.upi. } \\
\text { edu/index.php/jpmipa }\end{array}$ \\
\hline 8 & $\begin{array}{l}\text { Journal of Education and Learning/ } \\
\text { EduLearn }\end{array}$ & $\begin{array}{l}\text { Ahmad Dahlan University } \\
\text { (Universitas Ahmad Dahlan) }\end{array}$ & $\begin{array}{l}\text { http://journal.uad.ac.id/ } \\
\text { index.php/EduLearn/index }\end{array}$ \\
\hline 9 & $\begin{array}{l}\text { Journal of Education (Jurnal } \\
\text { Pendidikan/PARAMETER) }\end{array}$ & $\begin{array}{l}\text { State University of Jakarta } \\
\text { (Universitas Negeri Jakarta) }\end{array}$ & $\begin{array}{l}\text { http://journal.unj.ac.id/unj/ } \\
\text { index.php/parameter }\end{array}$ \\
\hline 10 & Sainsmat & $\begin{array}{l}\text { State University of Makassar } \\
\text { (Universitas Negeri Makassar) }\end{array}$ & $\begin{array}{l}\text { http://ojs.unm.ac.id/index. } \\
\text { php/sainsmat }\end{array}$ \\
\hline
\end{tabular}




\section{Critical challenges for the future of science education in Indonesia}

Indonesia has seen improvements in all sectors of education, teacher preparation, professional development, and research. To focus our attention on the future of science education in Indonesia, we conclude by highlighting significant developments in four areas, including 1) increasing educational attainment and accessibility to resources, 2) improving student achievement, 3) strengthening teacher preparation and professional development, and 4) expanding educational research and collaboration efforts. Building from these discussions, we identify critical challenges requiring additional attention for improving the overall quality of science education in Indonesia and suggest some pathways towards positive growth and development. This section offers readers context for considering the challenges that face Indonesia's science education community today and in the future.

\section{Equitable educational attainment opportunities and accessibility to resources}

Currently, data shows general equity in enrolment at the elementary and middle years levels for all students, regardless of gender, ethnicity, religion, economic status, and geographical location. However, national data also shows some differences in students' gross enrollment ratio by area, particularly for senior secondary and university levels. Statistics show that the gross enrollment ratio for the senior secondary in urban areas is $88 \%$ and in rural areas is only $73 \%$. Thus, more students remain in school for secondary education in urban areas. However, the gap is bigger at the university level, where the percentage for urban areas is $37 \%$ and rural areas is $17 \%$. The gap for drop-out ratio by area for senior secondary school is also higher in the rural areas $(\sim 4.3 \%)$ compared to urban areas $(\sim 2.7 \%$; BPS, 2017$)$. So educational attainment is not equal for all students in all regions.

Some of the differences in students' school participation and school drop-out rates can be attributed to disparities in economic opportunities for families, especially in rural provinces and in mountainous regions. Takahashi (2011) found that factors, such parental education and the socioeconomic status of local communities, are correlated to school enrollment rates. Students from wealthier families and students living in communities with a high proportion of students enrolled in school tend to attend school more regularly than students from economically disadvantaged families and who live in communities where peers are often absent from school. Also, the number of schools in this area may be limited and the access is difficult for students. For example, in Papua, the province with the highest percentage of people living in poverty and with a topography dominated by mountains, there are only about 3000 schools (elementary to senior secondary level) serving an area of more than $300,000 \mathrm{~km}$. As a result, there is only 1 school for every $100 \mathrm{~km}$ of land (BPS, 2017). Moreover, students may attend schools with insufficient material resources and facilities and may attract less qualified teachers than students attending schools in more affluent cities and suburbs.

A study by Luschei and Zubaidah (2012) reported that in nine small rural schools in the district of Bogor, West Java Province, the student-teacher ratio in was much higher than the national primary-level student-teacher ratio. This study demonstrates that schools in rural areas fail to attract teachers. In addition, not only are school facilities in poor and rural areas limited, but it can also be difficult for teachers and students to physically access these schools. The distance is so great that students need a vehicle or 
they may have to walk several kilometers across difficult terrain to reach the school. Teachers in these schools also receive insufficient pedagogical training programs, particularly about how to manage multi-grade classrooms. Many teachers already struggle to implement the curriculum, but in these rural areas, teachers have the added burden of trying to implement different grade and content curriculum for multiple students in the same classroom. Finding ways to diminish the inequities faced by teachers and students in poor and rural communities is an important area for policy and research in the future.

To address the needs of students in different communities, the government will need to not only provide better education facilities, but will also need to improve the training of teachers and develop additional curriculum and resources that are more relevant for these students and their communities (Rozenszajn \& Yarden, 2014). In addition, these communities would benefit from more economic resources to help attract and maintain high-quality educators over time.

The enactment of the National Education System Law in 2003 requires the central and local governments to allocate a minimum of $20 \%$ of their budgets to the educational sector in order to give more flexibility to the government in designing programs to address issues of equal opportunity and improvement of the national education system. The School Operational Funding program, enacted in 2005, is a good example of how financial support can be used to improve school facilities for students in different areas. Using this fund, school officials can provide laboratory and teaching facilities, improve instructional practices, support school-educational programs, and provide additional salaries for teachers.

Furthermore, the undergraduate scholarship program (Beasiswa Bidikmisi) for students with good academic performance who come from low-income families is also an effective way to increase students' opportunities to continue their education to the university level. Since 2010 the scholarship program has supported more than 352,000 students, of whom 87,000 have completed their bachelor's degrees. Continual implementation of these programs may help improve educational outcomes for students in these areas over time. Research is needed to determine the effectiveness of different policies on local classroom practices and their impact on student learning.

\section{Improving student achievement in science}

Currently, Indonesian students show low performance on both national and international assessments in science. Indonesian students' performance on the Program of International Student Assessment (PISA) has remained far below the international average. Since first joining the exam in 2000, Indonesia has consistently scored in the lowest achievement group. For example in 2013, Indonesian students ranked the second lowest of the 72 countries participating in the exam. However, on the 2015 assessment, students saw an increase of 21 points over their previous average. They improved their ranking to 62 nd out of 72 countries.

On similar assessments, such as the Trends in International Mathematics and Science Study (TIMSS), Indonesian students also struggle in science, scoring far below the international average on assessments in 1999, 2011, and 2015. Even on the National Exam (Ujian Nasional [UN]), Indonesian students struggle in science. In 2017, the 
average science score for students at the junior secondary school was only 50.72 out of 100, and for senior secondary students, the average was 36.48 out of 100 for science (biology, physics, and chemistry). These low scores are indicative of students' struggles to demonstrate their knowledge and understanding of science on these assessments and make clear that students need improved educational experiences to help expand their ability to perform well on these kinds of exams and to learn science. While there is optimism among educators that the revision of the national competencies and improvement of national standards for teaching and learning in the new science curriculum will have a positive impact on students' achievement, both locally and internationally, there are limits to what can be expected from the implementation of the new curriculum, as there is a need for additional supportive educational policies.

The school system in Indonesia requires students at the end of each secondary school level (Grades 9 and 12) to take the National Standardized School Exam (Ujian Sekolah Berstandar Nasional [USBN]). This exam will determine whether students can continue their education to the next level or not. Furthermore, the government also employs the National Exam (Ujian Nasional [UN]) system as an accountability measurement of the curriculum enactment. The government has stated that the USBN and UN are necessary to assess students' achievement of national education standards and that the results will be useful for monitoring schools' performance and for identifying schools in need of support. As a consequence, many schools are forced to prioritize students' preparation for successfully completing the UN and USBN exams. This policy runs the risk of having a negative impact on teachers' acceptance and implementation of the new curriculum reform measures, as some studies have shown that external high-stakes assessments can minimize teachers' ability to implement changes in real classroom settings (Ryder \& Banner, 2013). Moreover, accountability policies in countries with a national curriculum have been shown to place considerable pressure on teachers that encourage them to shift away from curriculum content to a focus more on test-oriented teaching (Creese, Gonzalez, \& Isaacs, 2016; Ryder, 2015). Therefore, given the significant impact of USBN and UN on the school practices, the government needs to consider carefully how such policies may not be well aligned with the curriculum reform goals.

\section{Strengthening teacher preparation and professional development}

New policies requiring that teachers continuously improve their skills and knowledge through on-going teacher professional development are expected to help improve teacher quality and lead to increases in student achievement over time. Involving teachers to work collaboratively in certain type of TPD program such Lesson Study (LS) can be an effective strategy and alternative to improve teachers' content knowledge and teaching skill (Handayani, Wilujeng, Prasetyo, \& Triyanto, 2018). These policies and the support that has been developed to successfully implement large-scale professional development are to be applauded. However, given the very diverse nature of Indonesian school populations and contexts, it is important for the government to ensure that the pre-service teacher curriculum programs reflect the needs of the schools where teachers will be working.

A positive example of this kind of locally developed program includes a partnership program between MGMP and TEIs to create workshops aimed at improving 
professional competence and pedagogical competence of chemistry teachers in the north Lombok region. The workshop involved 14 chemistry teachers from nine public senior secondary schools and science teacher educators who collaboratively worked to design lesson plans and teaching materials to engage students in inquiry learning activities. Afterwards, teachers practiced implemented the activities developed in the workshop in their own classrooms while being observed by their colleagues. Throughout the program, teacher educators provided support and guidance, and at the end of the program, teachers and teacher educators discussed and evaluated the overall components of the program and activities. The program was found to significantly improve teachers' professional and pedagogical competencies (Purwoko, Andayani, Muntar, \& Diartha, 2017). As a result, partnership programs such as this are viewed as beneficial for supporting improved collaboration between local teacher communities and TEIs and are increasingly being used to provide teacher professional development activities in more cities and districts throughout the province of West Nusa Tenggara.

Teacher education program that are grounded in local context and developed in collaboration with teachers have the potential to affect positive change in schools. As these programs grow and develop, we hope developers will heed research asserting the need to promote culturally and context-relevant pedagogical practices (Chang, Faikhamta, Na, \& Song, 2018) and to expose teachers to more educational research and theory about the need to value and understand students' backgrounds and out-of-school experience (Zhang \& Tang, 2017). For example, understanding the local school context where teachers work is important for ensuring what kinds of TPD programs are relevant and can be used by teachers in real classroom settings (Widodo \& Riandi, 2013).

One important way to determine what kinds of TPD would be useful for different groups of teachers and students is by expanding educational research initiatives focused on identifying the challenges facing teachers and students in Indonesian classrooms. In addition to conducting research, it is important to disseminate research findings to both teacher educators and practicing teachers. Unfortunately, the majority of TEIs are private teacher colleges that tend to have limited facilities and lack the resources necessary for effectively training prospective teachers to be ready to meet the many social and academic challenges they will face in the classroom. More emphasis needs to be placed on developing teacher education and systematically improving and ensuring the general quality of pre-service teacher programs. This is especially necessary for improving science education outcomes for K-12 students (Harjanto, Lie, Wihardini, Pryor, \& Wilson, 2018).

\section{Expanding educational research and collaboration efforts}

Finally, while the government is working hard to provide professional development opportunities for in-service teachers, government and non-government groups providing professional development need to consider more carefully teachers' needs when planning program content. One important way to determine what kinds of PD would be useful for different groups of teachers and students is by expanding educational research initiatives focused on identifying the challenges facing teachers and students in Indonesian classrooms. In addition to conducting research, it is important to disseminate research findings to both teacher educators and practicing teachers. 
A recent analysis of publications in from seven top-ranked international science education journals revealed very little research conducted in Indonesia has been published. In 402 combined years of publication history, only 16 papers included Indonesia in the title (see Table 8).

When expanding the search to include the abstract, an additional two papers were identified. In each case, there was at least one author representing a university or research institute in Indonesia. However, at least one paper included seven authors identified as working at institutes in Indonesia. The majority of the 16 papers published described findings from a comparative study in which data from Indonesia was used to compare teaching and learning outcomes with students in other countries. In general these papers failed to provide historical context for understanding the present challenges faced by teachers and students in these comparative analyses. We share this analysis to demonstrate the paucity of work available to inform educators about the fourth largest education system in the world. We hope this paper will inspire more researchers from Indonesia to share their research in international channels and that more colleagues external to Indonesia may become interested to learn about this unique and dynamic education system. We believe it is of critical importance for researchers from local contexts in the Asia-Pacific region to disseminate work to a wider international audience so we that may all benefit and learn from one another (Martin \& Chu, 2015).

Recently, the government has introduced various policies to promote educational research initiatives and collaboration in the higher education institution, particularly in TEIs, to improve the quality of research outcomes and the positive impact on educational practices in Indonesia. In 2016, the synergy between MRTHE and the Indonesia Endowment Fund for Education (Lembaga Pengelola Dana Pendidikan) provides scholarship programs for lecturers (Beasiswa Unggulan Dosen Indonesia) from public and private universities to pursue doctoral degrees at universities in Indonesia and overseas.

Table 8 Analysis of publications in top science education journals related to Indoensia

\begin{tabular}{|c|c|c|c|c|c|}
\hline \multirow[t]{2}{*}{ Journal Name } & \multirow{2}{*}{$\begin{array}{l}\text { Years of } \\
\text { Publication } \\
\text { (Total Years) }\end{array}$} & \multicolumn{3}{|c|}{$\begin{array}{l}\text { Term Indonesia/ } \\
\text { Indonesian included in: }\end{array}$} & \multirow[t]{2}{*}{$\begin{array}{l}\text { Authors } \\
\text { listed at }\end{array}$} \\
\hline & & Title & Abstract & Keyword & \\
\hline $\begin{array}{l}\text { International Journal of Science } \\
\text { Education }\end{array}$ & $\begin{array}{l}1979-2019 \\
\quad(40)\end{array}$ & 2 & 2 & - & 7 \\
\hline $\begin{array}{l}\text { Journal of Research in Science } \\
\text { Teaching }\end{array}$ & $\begin{array}{l}1960-2019 \\
(59)\end{array}$ & 2 & 3 & - & 1 \\
\hline Science Education & $\begin{array}{l}\text { 1910-2019 } \\
(109)\end{array}$ & 2 & - & - & 1 \\
\hline School Science and Mathematics & $\begin{array}{l}1900-2019 \\
(119)\end{array}$ & - & - & - & - \\
\hline Research in Science Teaching & $\begin{array}{c}1971-2018^{\mathrm{a}} \\
(48)\end{array}$ & 6 & 5 & & 1 \\
\hline Cultural Studies of Science Education & $\begin{array}{l}2007-2018^{a} \\
\quad(11)\end{array}$ & - & 1 & & 1 \\
\hline \multirow[t]{2}{*}{$\begin{array}{l}\text { International Journal of Science } \\
\text { and Mathematics Education }\end{array}$} & $\begin{array}{l}\text { 2003-2019 } \\
\quad(16)\end{array}$ & 4 & 7 & 2 & $17^{\mathrm{b}}$ \\
\hline & (402) & 16 & 18 & 2 & 28 \\
\hline
\end{tabular}

ajournal without 2019 issue at the time of analysis

bone paper included eight authors 
At the beginning stages of this program, there were around 2000 lecturers receiving scholarship support for study in more than 30 universities in Indonesia, including in TEIs, most of which are nationally top-ranked schools. Moreover, the scholarship program also supports 168 lecturers to study in more than 10 different countries, such the United Kingdom, Australia, Netherlands, Japan, and South Korea. Some of these scholars are studying in education and science education graduate degree programs. This program seeks to build an educational network with a wide range, both inside and outside of Indonesia, in order to provide good opportunities for lecturers to improve their research competency and collaboration at the national and international levels (MRTHE, 2016b). With these improvements, we can expect to see continued development and improvement in Indonesia's science education research, science teacher education, and student learning and achievement in science.

\section{Endnotes}

${ }^{1}$ BPS (Badan Pusat Statistik) is Indonesian Central Statistics Agency. BPS is a governmental institution that is responsible for the national census and survey. All BPS data can be accessed for free and is provided on their official website: https://www.bps.go.id/

${ }^{2}$ For clarity for Indonesian readers, Bahasa Indonesian terms are used to introduce specific people, places, and educational laws and policies. We do not include these terms in the list of abbreviations because the Bahasa and English language abbreviations are not equivalent. In addition, when possible, hyper links are provided to direct readers to government websites that show the laws and policies being discussed.

${ }^{3} \mathrm{MOEC}$ in Indonesia is called Kementerian Pendidikan dan Kebudayaan (https:// www.kemdikbud.go.id/)

${ }^{4}$ MORA in Indonesia is called Kementerian Agama (https://kemenag.go.id/)

${ }^{5}$ MRTHE in Indonesia is called Kementerian Riset, Teknologi, dan Pendidikan Tinggi (https://ristekdikti.go.id/)

${ }^{6}$ In Indonesia TEIs are called Lembaga Pendidikan Tenaga Kependidikan (LPTK).

${ }^{7}$ Most private TEIs are teachers' colleges (Sekolah Tinggi Keguruan dan Ilmu Pendidikan [STKIP]). These institutions solely offer programs for teacher education.

${ }^{8}$ This is the Seleksi Nasional Masuk Perguruan Tinggi Negeri (SNMPTN), one of the national selection processes for entering public universities based on students' academic records. This selection is conducted earlier than SBMPTN.

${ }^{9}$ This is the Seleksi Bersama Masuk Perguruan Tinggi Negeri (SBMPTN), another national selection process for entering public universities by sitting for the entrance exam.

${ }^{10}$ In Indonesia $\mathrm{S} 1$ is the abbreviation for Bachelor's degree and is commonly used to indicate academic programs for Bachelor study, 'S' comes from word 'Sarjana' which means Bachelor and '1' indicates the first level of post-secondary school.

Abbreviations

BPS: Badan Pusat Statistik/ Indonesian Central Statistics Agency; BUMN: Badan Usaha Milik Negara/ State-Owned Enterprises; IGI: Ikatan Guru Indonesia/ Indonesian Teacher Association; KBK: Kurikulum Berbasis Kompetensi/ CompetencyBased Curriculum; KD: Kompetensi Dasar/ Basic Competencies; Kl: Kompetensi Inti/ Main Competencies; KTSP: Kurikulum Tingkat Satuan Pendidikan/ School-Based Curriculum; MGMP: Musyawarah Guru Mata Pelajaran/ Subject-Based Teacher Groups; MOEC: Ministry of Education and Culture; MORA: Ministry of Religious Affairs; MRTHE: Ministry of Research, Technology, and Higher Education; PGRI: Persatuan Guru Republik Indonesia/ Indonesian Teacher Union; PLPG: Pendidikan dan Latihan Profesi Guru/ Teacher Professional Education and Training; PPG: Pendidikan Profesi Guru/ Teacher Professional Education; SSS: Senior Secondary School; TEl: Teacher Education Institution 


\section{Acknowledgements}

This work was supported by the Ministry of Education of the Republic of Korea and the National Research Foundation of Korea (NRF-2016S1A3A2925401). This work was also supported by the Ministry of Finance of the Republic of Indonesia and the Indonesia Endowment Fund for Education.

\section{Funding}

This work was supported by the Ministry of Education of the Republic of Korea and the National Research Foundation of Korea (NRF-2016S1A3A2925401). This work was also supported by the Ministry of Finance of the Republic of Indonesia and the Indonesia Endowment Fund for Education.

\section{Authors' contributions}

All authors contributed equally to this work. All authors commented on the manuscript at all stages. All authors read and approved the final manuscript.

\section{Authors' information}

Faisal is a doctoral candidate in Biology Education Department at the Seoul National University in Seoul, Republic of Korea. Prior to attending university in Korea, Faisal work as lecturer in the Biology Education Department at the State University of Makassar in Indonesia. His research focuses on developing effective teaching strategies in science. He is particularly interested in designing a socio-scientific issues (SSI)-based instructional program for pre-service science teachers to be used in Indonesian teacher education programs.

Sonya N Martin is an Associate Professor in the Department of Earth Science Education at Seoul National University in Seoul, Republic of Korea. Sonya holds a bachelor's degree in Biology from Bryn Mawr College, and master's degrees in Elementary Education and in Chemistry Education from the University of Pennsylvania in the United States. She also holds a doctoral degree in Science Education from Curtin University in Australia. Her research focuses on identifying science teacher practices that promote learning for diverse students and on promoting professionalization of science teachers through classroom-based participatory research.

\section{Ethics approval and consent to participate}

The data collected from this article did not involve human subjects so no human subjects approval was necessary.

\section{Consent for publication}

The authors agree that this article will be published in the APSE journal.

\section{Competing interests}

The authors declare that they have no competing interests.

\section{Publisher's Note}

Springer Nature remains neutral with regard to jurisdictional claims in published maps and institutional affiliations.

\section{Author details}

'Graduate School of Science Education, Seoul National University, Seoul, Republic of Korea.

${ }^{2}$ Biology Education Department, State University of Makassar, Makassar, Indonesia.

${ }^{3}$ Earth Science Education Department, Seoul National University, Seoul, Republic of Korea.

Received: 26 December 2018 Accepted: 4 March 2019

Published online: 25 April 2019

\section{References}

Ananta, A., Arifin, E. N., Hasbullah, M. S., Handayani, N. B., \& Pramono, A. (2015). Demography of Indonesia's ethnicity. Singapore: Institute of Southeast Asian Studies.

Azra, A. (2008). Indonesian higher education: From public good to privatization. Journal of Asian Public Policy, 1(2), 139-147. https://doi.org/10.1080/17516230802094411.

Bangay, C. (2005). Private education: Relevant or redundant? Private education, decentralisation and national provision in Indonesia. Compare: A Journal of Comparative and International Education, 35(2), 167-179. https://doi.org/10.1080/ 03057920500129742.

Bjork, C. (2004). Decentralisation in education, institutional culture and teacher autonomy in Indonesia. International Review of Education, 50, 245-262 Available from: https://link.springer.com/content/pdf/10.1007\%2Fs11159-004-2622-6.pdf.

BPS. (2010). Penduduk menurut wilayah dan agama yang dianut [Population by religion]. Jakarta: Badan Pusat Statistik. Retrieved from https://sp2010.bps.go.id/index.php/site/tabel?tid=321

BPS. (2014). Penduduk Indonesia menurut provinsi 1971, 1980, 1990, 1995, 2000 dan 2010 [Population of Indonesia by province 1971, 1980, 1990, 1995, 2000 and 2010]. Jakarta: Badan Pusat Statistik. Retrieved from https://www.bps.go.id/ statictable/2009/02/20/1267/penduduk-indonesia-menurut-provinsi-1971-1980-1990-1995-2000-dan-2010.html .

BPS. (2016). Luas daerah dan jumlah pulau menurut provinsi, 2002-2016 [Total area and number of islands by province, 2002-2016]. Jakarta: Badan Pusat Statistik. Retrieved from https://www.bps.go.id/statictable/2014/09/05/1366/luasdaerah-dan-jumlah-pulau-menurut-provinsi-2002-2016.html .

BPS. (2017). Potret pendidikan Indonesia, statistik pendidikan 2017 [Portrait of Indonesian education, educational statistic 2017]. Jakarta: Badan Pusat Statistik.

Chang, J., Faikhamta, C., Na, J., \& Song, J. (2018). A comparison of science classroom environments between Korea and Thailand with a focus on their cultural features. Asia-Pacific Science Education, 4(11), 1-22. https://doi.org/10.1186/s41029-018-0028-1. 
Creese, B., Gonzalez, A., \& Isaacs, T. (2016). Comparing international curriculum systems: The international instructional systems study. The Curriculum Journal, 27(1), 5-23. https://doi.org/10.1080/09585176.2015.1128346.

Handayani, R. D., Wilujeng, I., Prasetyo, K. Z., \& Triyanto. (2018). Building an indigenous learning community through lesson study: Challenges of secondary school science teachers. International Journal of Science Education. https://doi.org/10. 1080/09500693.2018.1548789.

Harjanto, I., Lie, A., Wihardini, D., Pryor, L., \& Wilson, M. (2018). Community-based teacher professional development in remote areas in Indonesia. Journal of Education for Teaching, 44(2), 212-231. https://doi.org/10.1080/02607476.2017.1415515.

Heyward, M. O., Cannon, R. A., \& Sarjono. (2011). Implementing school-based management in Indonesia: Impact and lessons learned. Journal of Development Effectiveness, 3(3), 371-388. https://doi.org/10.1080/19439342.2011.568122.

Hill, H., \& Thee, K. W. (2012). Indonesian universities in transition: Catching up and opening up. Bulletin of Indonesian Economic Studies, 48(2), 229-251. https://doi.org/10.1080/00074918.2012.694156.

Luschei, T. F., \& Zubaidah, I. (2012). Teacher training and transitions in rural Indonesian schools: A case study of Bogor, West Java. Asia Pacific Journal of Education, 32(3), 333-350. https://doi.org/10.1080/02188791.2012.711241.

Martin, S.N., \& Chu, H.E. (2015). Asia-Pacific Science Education (APSE): Expanding opportunities for publishing science education research. Asia-Pacific Science Education, 1:3, 1-18. https://doi.org/10.1186/s41029-015-0006-9.

MOEC (Ministry of Education and Culture). (2013). Peraturan menteri pendidikan dan kebudayaan republik indonesia nomor 69 tahun 2013 tentang kerangka dasar dan struktur kurikulum sekolah menengah atas/madrasah aliyah [Act Ministry of Education and Culture no. 69 of 2013 about curriculum structure for senior secondary education]. Jakarta: Ministry of Education and Culture. Retrieved on March 14, 2019 from http://biologiffip.uns.ac.id/wp-content/uploads/2013/08/PDK2013-69-Kerangka-Dasar-Kurikulum-Kompetensi-SMA.pdf.

MOEC (Ministry of Education and Culture). (2016a). Peraturan Menteri Pendidikan dan Kebudayaan Republik Indonesia Nomor 20 Tahun 2016 Tentang Standar Kompetensi Lulusan Pendidikan Dasar dan Menengah [Act Ministry of Education and Culture no. 20 of 2016 about competency standard for elementary and secondary education]. Jakarta: Ministry of Education and Culture. Retrieved on March 14, 2019 from http://bsnp-indonesia.org/wp-content/uploads/2009/04/Permendikbud_ Tahun2016_Nomor020_Lampiran.pdf

MOEC (Ministry of Education and Culture). (2016b). Peraturan Menteri Pendidikan dan Kebudayaan Republik Indonesia Nomor 21 Tahun 2016 Tentang Standar Isi Pendidikan Dasar dan Menengah [Act Ministry of Education and Culture no. 21 of 2016 about content standard for elementary and secondary education]. Jakarta: Ministry of Education and Culture. Retrieved on March 14, 2019 from http://bsnp-indonesia.org/wp-content/uploads/2009/06/Permendikbud_Tahun2016_Nomor021_ Lampiran.pdf

MOEC (Ministry of Education and Culture). (2016c). Peraturan Menteri Pendidikan Dan Kebudayaan Republik Indonesia Nomor 29 Tahun 2016 Tentang Sertifikasi Bagi Guru yang Diangkat Sebelum Tahun 2016 [Act of Ministry of Education and Culture no. 29, 2016 about professional teacher certification]. Jakarta: Ministry of Education and Culture. Retrieved on March 14, 2019 from https://jdih.kemdikbud.go.id/arsip/ABSTRAKSI\%20PERMENDIKBUD\%2029-2016.pdf.

MOEC (Ministry of Education and Culture). (2016d). Peraturan Menteri Pendidikan Dan Kebudayaan Republik Indonesia Nomor 8 Tahun 2016 Tentang Buku yang Digunakan oleh Satuan Pendidikan [Act of Ministry of Education and Culture no. 8, 2016 about National Textbook for school]. Jakarta: Ministry of Education and Culture. Retrieved on March 14, 2019 from http:// simpuh.kemenag.go.id/regulasi/permendikbud_08_16.pdf.

MOEC (Ministry of Education and Culture). (2017). Peraturan Menteri Pendidikan Dan Kebudayaan Republik Indonesia Nomor 26 Tahun 2017 Tentang Tentang Petunjuk Teknis Bantuan Operasional Sekolah [Act of Ministry of Education and Culture no. 26, 2017 about technical guidelines for school operational fund]. Jakarta: Ministry of Education and Culture. Retrieved on March 14, 2019 from https://jdih.kemdikbud.go.id/arsip/Permendikbud_Tahun2017_Nomor026.pdf.

MRTHE (Ministry of Research, Technology, and Higher Education). (2016a). Revitaliasi LPTK. (Revitalization of Teacher Education Institutions). Jakarta: Ministry of Research, Technology, and Higher Education. from https://ristekdikti.go.id/wp-content/ uploads/2016/01/RAKERNAS-REFORMASI-LPTK.pdf. Accessed 10 Oct 2018.

MRTHE (Ministry of Research, Technology, and Higher Education). (2016b). 2016 Laporan Tahun Kementerian Riset, Teknologi, dan Pendidikan Tinggi. (2016 Annual Report of Ministry of Research, Technology, and Higher Education).Jakarta: Ministry of Research, Technology, and Higher Education. Retrieved on March 14, 2019 from https://ristekdikti.go.id/wp-content/ uploads/2017/07/Buku-Laporan-Tahunan-2016.pdf

MRTHE (Ministry of Research, Technology, and Higher Education). (2017). Peraturan Menteri Riset, Teknologi, Dan Pendidikan Tinggi Republik Indonesia Nomor 90 Tahun 2017 Tentang Penerimaan Mahasiswa Baru Program Sarjana Pada Perguruan Tinggi Negeri [Act of Ministry of Research, Technology, and Higher Education no. 90 of 2017 about new student admissions of undergraduate programs at state universities]. Jakarta: Ministry of Research, Technology, and Higher Education. Retrieved on March 14, 2019 from http://jdih.ristekdikti.go.id/view-file/?id=3408c4ca-fc95-4792-89f4-a0367c0a0976.

Munandar, A. S. (1990). Indonesian managers, today and tomorrow. International Journal of Psychology, 25(3-6), 855-869. https://doi.org/10.1080/00207599008247932.

OECD (Organisation for Economic Co-operation and Development)/ Asian Development Bank. (2015). Education in Indonesia: Rising to the challenge. Paris: OECD Publishing. https://doi.org/10.1787/9789264230750-en.

Parker, L. (2017). Religious environmental education? The new school curriculum in Indonesia. Environmental Education Research, 23(9), 1249-1272. https://doi.org/10.1080/13504622.2016.1150425.

Purnastuti, L., Miller, P. W., \& Salim, R. (2013). Declining rates of return to education: Evidence for Indonesia. Bulletin of Indonesian Economic Studies, 49(2), 213-236. https://doi.org/10.1080/00074918.2013.809842.

Purwoko, A. A., Andayani, Y., Muntar, \& Diartha, I. N. (2017). Efforts in improving teachers' competencies through collaboration between teacher forum on subject matter (MGMP) and pre-service teacher training institution (LPTK). Jurnal Pendidikan IPA Indonesia, 6(1), 11-15.

Rahmi. (2015). The development of language policy in Indonesia. Englisia, 3(1), 9-22. from https://jurnal.ar-raniry.ac.id/index. php/englisia/article/view/622/934. Accessed 10 Sept 2018.

Rozenszajn, R., \& Yarden, A. (2014). Expansion of biology teachers' pedagogical content knowledge (PCK) during a long-term professional development program. Research in Science Education, 44, 189-213. https://doi.org/10.1007/s11165-013-9378-6.

Ryder, J. (2015). Being professional: Accountability and authority in teachers' responses to science curriculum reform. Studies in Science Education, 51(1), 87-120. https://doi.org/10.1080/03057267.2014.1001629. 
Ryder, J., \& Banner, I. (2013). School teachers' experiences of science curriculum reform. International Journal of Science Education, 35(3), 490-514. https://doi.org/10.1080/09500693.2012.665195.

Sari, E. R. (2012). Online learning community: A case study of teacher professional development in Indonesia. Intercultural Education, 23(1), 63-72. https://doi.org/10.1080/14675986.2012.664755.

Soebari, T., \& Aldridge, J. M. (2016). Investigating the differential effectiveness of a teacher professional development programme for rural and urban classrooms in Indonesia. Teacher Development, 20(5), 701-722. https://doi.org/10.1080/ 13664530.2016.1185031

Suryadarma, D., Suryahadi, A., Sumarto, S., \& Rogers, H. (2006). Improving student performance in public primary schools in developing countries: Evidence from Indonesia. Education Economics, 14(4), 401-429. https://doi.org/10.1080/ 09645290600854110.

Takahashi, K. (2011). Determinants of Indonesian rural secondary school enrolment: Gender, neighbourhood and school characteristics. Bulletin of Indonesian Economic Studies, 47(3), 395-413. https://doi.org/10.1080/00074918.2011.619053.

Widodo, A., \& Riandi. (2013). Dual-mode teacher professional development: Challenges and re-visioning future TPD in Indonesia. Teacher Development, 17(3), 380-392. https://doi.org/10.1080/13664530.2013.813757.

Zhang, D., \& Tang, X. (2017). The influence of extracurricular activities on middle school students' science learning in China. International Journal of Science Education, 39(10), 1381-1402. https://doi.org/10.1080/09500693.2017.1332797.

Submit your manuscript to a SpringerOpen ${ }^{\circ}$ journal and benefit from:

- Convenient online submission

- Rigorous peer review

Open access: articles freely available online

High visibility within the field

- Retaining the copyright to your article

Submit your next manuscript at $>$ springeropen.com 